\title{
Polygenic Obesity in Humans
}

\author{
Anke Hinney Johannes Hebebrand \\ Department of Child and Adolescent Psychiatry and Psychotherapy, University of Duisburg-Essen, Essen, Germany
}

Key Words

Genome wide association · Linkage · FTO

\section{Summary}

The molecular genetic analysis of obesity has led to the identification of a limited number of confirmed major genes. While such major genes have a clear influence on the development of the phenotype, the underlying mutations are however (extremely) infrequent and thus of minor clinical importance only. The genetic predisposition to obesity must thus be polygenic; a number of such variants should be found in most obese subjects; however, these variants predisposing to obesity are also found in normal weight and even lean individuals. Therefore, a polygene can only be identified and validated by statistical analyses: the appropriate gene variant (allele) occurs more frequently in obese than in non-obese subjects. Each single polygene makes only a small contribution to the development of obesity. The 103lle allele of the Val103lle single nucleotide polymorphism (SNP) of the melanocortin-4 receptor gene (MC4R) was the first confirmed polygenetic variant with an influence on the body mass index (BMI); the more common Val103 allele is more frequent in obese individuals. As determined in a recent, large-scaled meta-analysis the effect size of this allele on mean BMI was approximately $-0.5 \mathrm{~kg} / \mathrm{m}^{2}$. The first genome-wide association study (GWA) for obesity, based on approximately 100,000 SNPs analyzed in families of the Framingham study, revealed that a SNP in the proximity of the insulin-induced gene 2 (INSIG2) was associated with obesity. The positive result was replicated in independent samples; however, some other study groups detected no association. Currently, a meta-analysis is ongoing; its result will contribute to the evaluation of the importance of the INSIG2 polymorphism in body weight regulation. SNP alleles in intron 1 of the fat mass and obesity associated gene (FTO) confer the most relevant polygenic effect on obesity. In the first GWA for extreme early onset obesity we substantiated that variation in FTO strongly contributes to early onset obesity.

\section{Introduction}

Genetic mechanisms of body weight regulation are complex; there is presumably a substantial number of genes involved in common obesity. Gene variants (alleles) that have a small influence on body weight are termed polygenes. Alleles associated with obesity are common in the general population. Those polygenic variants presumably account for most of the genetic variation relevant in human body weight regulation; obesity results via the interaction of several of such polygenic variants and their combined interaction with environmental factors. Interindividual heterogeneity is most likely pronounced and implies that the specific set of polygenes entailing obesity in one individual is unlikely to be the same in another randomly selected obese subject.

Most of the initially confirmed genetic influences on obesity were found to be conferred by a single gene either with a recessive (e.g. resulting in leptin deficiency) or dominant (e.g. reduction in melanocortin-4 receptor tone) mode of inheritance. In contrast, polygenic effects are each rather small, a single polygene frequently affects a substantial proportion of obese individuals and, to a somewhat lesser extent, normal weight and even lean individuals. Associations between genetic variants and common human disorders such as obesity could have implications for diagnosis and risk prediction, prevention and treatment. Two gene variants with small but replicable effects on body weight have unambiguously been identified so far (melanocortin-4 receptor gene (MC4R) [1-3]; fat mass and obesity associated gene (FTO) [4-8]); for a third one (insulin-induced gene 2 (INSIG2)), initial positive data were not confirmed by others [9-13] so that a final evaluation of the role of this gene in weight regulation is currently awaited.

\begin{tabular}{ll}
\hline KARGER & $\oplus$ 2008 S. Karger GmbH, Freiburg \\
Fax +497614520714 & Accessible online at: \\
$\begin{array}{l}\text { E-mail Information@Karger.de } \\
\text { www.karger.com }\end{array}$ & www.karger.com/ofa
\end{tabular}




\section{Methodological Approaches Used for Detection of Obesity Genes}

Two major routes have been followed for the detection and analysis of a candidate gene (polygene or major gene) in body weight regulation.

\section{Candidate Gene Analyses}

Several genes have been analyzed in humans because they were found to be involved in central or peripheral pathways controlling energy intake and expenditure in animal models. Identification of a candidate gene can also be based on other knowledge, for instance pharmacological findings or location of a gene within a linkage region. A huge number of association studies for obesity involving cases and controls or, less frequently, families comprising one or more affected children and both parents have been performed; for a small number of genes meta-analyses have been carried out. A current list of positive results is depicted in the online version of the 'Obesity Gene Map' (http://obesitygene.pbrc.edu/). The respective last print version [14] lists positive associations for obesity phenotypes for a total of 113 candidate genes (e.g. uncoupling protein 2 and 3 (UCP2 and $U C P 3$ ), beta-3-adrenergic receptor $(B 3 A R)$, peroxisome proliferator-activated receptor-gamma $(P P A R G))$. However, only for 18 genes a minimum of five positive studies had been reported; frequently the study groups were small [14]. The first truly validated polygenic effect on body weight (Val103Ile polymorphism in MC4R) was detected via a candidate gene analysis [1].

\section{Genome-Wide Approaches}

\section{Genome-Wide Linkage Scans}

Genome-wide linkage scans identify chromosomal regions harboring one or more genes relevant for the respective phenotype. The regions underlying linkage peaks are narrowed down by fine mapping so that candidate gene analyses can be pursued. Several microsatellite-based genome-wide linkage scans have been performed for obesity in adults. Because single formal genetic studies suggest a higher heritability of body weight in adolescence [15] and because genes that influence body weight in adulthood might not be the same as those that are relevant in childhood and adolescence [16], whole genome scans were also performed in young obese individuals. However, the number of linkage studies in early-onset obesity is rather small [17-19]. Although linkage studies have been performed for obesity and related phenotypes since 1997 [20], it took until 2003 to identify two candidate genes possibly underlying the linkage peaks on chromosomes 10 or $\mathrm{X}[21,22]$; neither of the two genes has been unequivocally validated in several large and independent samples. In 2005, the first candi- date gene for early onset obesity detected via a genome linkage scan was identified (ENPP1) [23]; attempts are ongoing to validate this association. Interestingly, the region on chromosome 16 harboring the currently most relevant polygene FTO (see below) was detected in a meta-analysis of 37 genomewide linkage studies comprising data on more than 31,000 individuals from over 10,000 families [24]. However, the combined analysis of these genome-wide linkage studies revealed that, despite having substantial statistical power, specific chromosomal regions for BMI or obesity were not unequivocally detected [24]. This most likely indicates that the effect sizes of genes influencing adiposity are small to very small, and, in addition, suggests substantial genetic heterogeneity and variable dependence on environmental factors.

In general, linkage studies have primarily been successful in detecting genes underlying monogenic disorders; however, they have only limited power to detect the genes of modest or small effect (oligogenes, polygenes) underlying complex disorders. To detect such polygenes, thousands of sib-pairs would be required [25].

\section{Genome-Wide Association Studies}

Genome-wide association (GWA) approaches have a far greater power to detect these minor gene effects [25]. In 2006 and 2007 the first two polygenes were identified by GWA studies. Current advances in chip technology made high-density single nucleotide polymorphism(SNP)-based GWA studies feasible, which only recently have led to the identification of a number of confirmed genes for different complex disorders [26].

\section{The Importance of Validating Initial Findings and Determining Effect Sizes}

To identify polygenic effects, associations in large and independent samples need to be initially detected and subsequently confirmed to firmly establish the role of a risk allele. In this context, stratification according to weight class is a reasonable approach. Individuals could hence be categorized as underweight, normal weight, overweight, obese or extremely obese; the frequency of an allele predisposing to obesity would accordingly be expected to increase in a systematic fashion. However, initially the direction of the effect of a particular allele is unknown; it could either predispose to obesity or leanness. Based on the thrifty genotype hypothesis [27] it can be speculated that the more common allele should in the majority of cases predispose to obesity; however, the currently very limited number of validated polygenes precludes any systematic assessment. For every particular candidate gene, initial findings need to be confirmed, irrespective of the approach leading to the gene identification [28]. Stringent efforts to confirm (or reject) an original finding are absolutely crucial; due to the low effect sizes and possible gene-environment interactions it is to be expected that several studies will not be able to confirm a true-positive finding. 
An impressive amount of positive association studies has been published so far; a systematic follow-up was described just for a minority of these [14]. The majority of positive studies have not been corrected for multiple testing. Different phenotypes are frequently tested for, in addition, subgroup analyses (e.g. based on age or gender) are common. Researchers typically do not correct for the total number of association studies performed by their group. Hence any initially reported 'significant' finding should be viewed critically and not be taken for granted until confirmed in independent, sufficiently powered studies. To avoid publication bias, the scientific community must provide ways and means to publish negative results. The researchers need to be aware of this responsibility. Standards for publication of such negative findings should be high. If negative findings represent an unsuccessful attempt to confirm an initial positive study, the power of the study for the given effect should be stated to allow a better interpretation of the negative results. It is necessary to pursue studies designed to confirm an initial finding in a very systematic fashion and to provide all the information which could later be of importance for a meta-analysis. The scientific community can only obtain a balanced opinion of mixed results obtained in different studies, if samples (and sampling strategies) leading to positive findings are delineated in detail. For this purpose, defined casecontrol and epidemiological/representative population samples could be referred to. Large trio samples allow for transmission disequilibrium tests (TDT) [29] and circumvent the problem of false-positive results based on population stratification. Additionally, meta-analyses are of utmost importance, once a sufficient number of studies has been published. More recently, single large-scale studies have simultaneously reported the initial finding and a meta-analysis based on a larger number of subsequently analyzed study groups $[4,9]$. Eventually, a decision needs to be reached as to whether current evidence is sufficient to unequivocally conclude that a particular allele is relevant for the phenotype. Whenever possible and feasible the decision should be based on large epidemiological studies and on a meta-analysis of all available studies. As a general rule, clinical (e.g. assessment of the relevance of an obesity allele for comorbid conditions), epidemiological and functional studies only appear warranted if an initial association finding has been unequivocally confirmed. Otherwise, the risk of pursuing falsepositive findings appears substantial.

\section{Melanocortin-4 Receptor Gene}

The necessity to validate findings can best be illustrated by delineating findings obtained for the obesity gene that has up to now been investigated most frequently: the $M C 4 R$. The $M C 4 R$ was originally viewed as a candidate gene for obesity in light of a rodent study showing an elevated body weight of heterozygous knock-out mice and clear-cut obesity in homozygous knockouts [30]. Many groups pursued mutation screens of the $M C 4 R$ after the initial detection of a small number of different mutations in obese humans only [31-33]. Currently, more than 90 different infrequent non-synonymous, nonsense and frame shift mutations in the MC4R have been described, mostly in extremely obese individuals [e.g. 33-37]. In vitro assays showed that most of these mutations lead to total or partial loss of function. Among extremely obese individuals combined frequencies for all functionally relevant mutations typically range from 2 to $5 \%$; approximately $0.5 \%$ of the normal weight population also harbors such mutations. Mutations are possibly more common in extremely obese children than in adults with extreme adiposity. It is widely assumed that such mutations entail monogenic obesity with an autosomal dominant mode of inheritance. However, the obesogenic effect of such mutations was not confirmed in a population-based sample [35], in which a total of six carriers were all within the normal weight range, thus clearly necessitating further research as to the relevance of these mutations at the population level.

The quantitative effect of functionally relevant human $M C 4 R$ mutations on body weight was determined in a family setting based on obese index cases harboring a mutation. Carriers of these mutations had significantly higher current BMI than their wild-type relatives. This amounted to 4.5 and $9.5 \mathrm{~kg} / \mathrm{m}^{2}$ in males and females, respectively. Additional genetic and/or environmental factors are obviously also operative in these families, which accordingly also contribute to the obesity of the index cases [38]. It is thus a matter of debate as to whether these mutations are really indicative of monogenic obesity. We would rather prefer to term the $M C 4 R$ as an oligogene.

Interestingly, the $M C 4 R$ can also be considered as a polygene: It was shown that unexpectedly the minor allele of one (Val103Ile, rs2229616) of two MC4R polymorphisms is negatively associated with obesity [1-3]. In light of the infrequency of this polymorphism and the small effect size, large study groups had to be screened. Several groups detected Val103Ile [e.g. 33, 34, 39]; heterozygotes for the 103Ile allele were identified in $2-9 \%$ of subjects of these different populations [1]. This polymorphism had originally been considered as irrelevant for body weight regulation because both association and functional studies had initially been negative. However, a family-based TDT [29] in 520 trios ascertained via an obese child or adolescent revealed a reduced transmission of the Ile103 allele (10 transmissions versus 25 non-transmissions; $p=0.02$ ). This unexpected finding led to a meta-analysis. Most groups had reported a (slightly) higher frequency of the Ile103 allele in controls than in obese cases. A meta-analysis comprising 7,713 individuals in total (3,631 obese cases and 4,082 controls), including novel data and all previously published reports, substantiated the evidence for a negative association of the Ile103 allele with obesity (odds ratio (OR) 0.69; 95\% confidence interval (95\%-CI) 0.59-0.99). An effect estimate of $-0.48 \mathrm{~kg} / \mathrm{m}^{2}$ was calculated for Ile103 carriers ( $\mathrm{p}=0.22$; sexand age-adjusted regression analysis), which is approximately equivalent to a reduction of $1.5 \mathrm{~kg}$ in a $1.8 \mathrm{~m}$ tall individual [1]. 
In light of previously negative functional findings, the two receptor variants were again compared in in vitro assays [1]. However, differences were not found although minor functional alterations are difficult to exclude via such assays. Additionally, the 5' and 3 ' regions of the $M C 4 R$ coding region were re-sequenced, and four other SNPs were detected, three of which were in total linkage disequilibrium with the original polymorphism. None of these readily explained the negative association with obesity [1]. The negative association of 103Ile with obesity could later be reconfirmed in a large epidemiological study group comprising 7,937 individuals [2]. Recently, a second meta-analysis encompassing a total of 29,563 individuals also confirmed the initial finding [3].

As the Val103Ile polymorphism showed normal endogenous agonist binding properties and normal cell surface receptor expression levels, it had been difficult to link the Ile103 allele with a potential molecular effect. Recently, the 103Ile MC4R revealed a modest (two-fold) but statistically significant decrease in antagonist hAGRP(87-132) potency, which is consistent with the obesity protective effect conferred by this variant [40]. The effect of $\beta-\mathrm{MSH}$, a potent agonist at the MC4R [41], seemed to be increased for the MC4R-103Ile [40]. Hence, both, the lower antagonist and the increased agonist potencies are compatible with an improved MC4R function, which could explain the weight reducing effect of the variant.

Recently, the contribution of the second non-synonymous polymorphism Ile251Leu to obesity was analyzed in 16,797 individuals of European origin from nine independent case-control, population-based and familial cohorts. In eight of nine studies a consistent negative association of 251Leu variant (prevalence between $0.41-1.21 \%$ ) with both childhood and extreme adult obesity (OR ranging from 0.25 to $0.76 ; \mathrm{p}<0.05$ ) and with modulation of BMI in the general populations was shown. Meta-analyses of previously published and novel data provided strong evidence of the protective effect of MC4R251Leu toward obesity $\left(\mathrm{OR}=0.52, \mathrm{p}=3.58 \times 10^{-5}\right)$ [42].

To conclude, the MC4R has been shown to harbor a total of more than 90 rare mutations, which in most cases have been shown to result in a reduced receptor function in in vitro studies. Based on a comparison of family members with and without functionally relevant mutations, the effect sizes of such mutations were found to on average be in the magnitude of 4.5 and $9 \mathrm{~kg} / \mathrm{m}^{2}$ in males and females, respectively. In addition, polygenic effects in the range of $0.5 \mathrm{~kg} / \mathrm{m}^{2}$ have been attributed to the two polymorphisms in this gene. Thus, genetic variants in this receptor gene can strongly predispose to obesity or provide a minor protective effect.

\section{The Novel Strategy: Identification of Polygenes via Genome-Wide Association Studies}

Recently GWA studies have become feasible through major improvements in high-throughput chip technologies that can process hundreds of thousands of SNPs quickly and affordably. The power of GWA studies for the detection of genes/alleles for different complex disorders has recently been proven [43, 44]. Especially for type 2 diabetes mellitus (T2DM) $[4,6,7,45,46]$ the progress has been impressive. Two obesity findings merit consideration.

\section{Insulin-Induced Gene 2}

694 individuals from 288 families of the Framingham Heart Study were screened by a dense, whole-genome scan (Mapping 100K Set; Affymetrix, Santa Clara, CA, USA). In both children and adults a common single nucleotide polymorphism (SNP; rs7566605) in the vicinity of the INSIG2 was found to be associated with obesity. Confirmation of the initial finding was shown in four of five separate samples comprised of individuals of Western European ancestry, African Americans or German children and adolescents. Approximately $10 \%$ of the individuals harbored the CC genotype that predisposes to obesity irrespective of their ethnicity [9].

The GWA in the Framingham families was performed employing a novel test strategy for quantitative traits in a familybased design [47, 48]. The problem of multiple comparisons was circumvented by an analysis that uses an initial screening and a subsequent test step (Pedigree-Based Association Test; PBAT) $[48,49]$. In the screening step the parental genotypes were used to select the SNPs and genetic models that best predicted the phenotypes of the offspring. The subsequent test step relied on a family-based association test (FBAT) [50] to test only the previously selected SNPs for association with obesity using measured genotypes of the offspring. FBAT is a more general version of the TDT [29], assessing transmission disequilibrium of an allele from the parents to the offspring in relation to the phenotype. For this procedure it is crucial that the measured genotypes of the offspring are only used for the test, but not for the screening step. As the screening step stochastically selected the alleles that are putatively transmitted from the parent to the offspring, the test step (FBAT) is statistically independent from the screening step. Thus, the analyses in the screening step do not bias the significance level of the subsequently performed FBAT analyses [47]. Hence, it is only necessary to adjust FBAT results for the number of comparisons performed during the test step. Therefore, the SNP(s) that reaches significance after adjustment for the number of tests performed in the test step is considered significant at a genome-wide level [47].

Herbert et al. [9] analyzed the 10 SNPs with the highest power estimates in the screening step for association using FBAT [51, 52]. Only one SNP (rs7566605) turned out to be significant after this test procedure ( $\mathrm{p}=0.0026$; after correction for testing 10 SNPs $\mathrm{p}=0.026)$. The SNP is located $10 \mathrm{~kb}$ upstream of the INSIG 2 gene. The recessive effect on obesity was conferred by the $\mathrm{C}$ (minor) allele [9], as already detected in the 
original screening step. The OR of the effect was 1.3 , hence, the risk for $\mathrm{CC}$ homozygotes to become obese was increased by about $30 \%$. The average increase in BMI conferred by the risk genotype was approximately 1 BMI unit. However, apart from four independent confirmations the study also reported a non-confirmation in the 'Nurses Health Study'. The authors related the lack of association to the proportionately lower number of individuals with high BMI among the 2,726 individuals of this as compared to the other study groups.

One of the confirmatory samples comprised study groups from Poland and the USA (1,775 cases and 926 controls), which were combined for the analysis as there was no evidence of heterogeneity. The single study groups would not have resulted in a confirmation. In three independent familybased samples and three studies of unrelated individuals the rs7566605 CC genotype was associated with obesity. The best singular $\mathrm{p}$ value was obtained in 368 German parent-child trios in which either a child or adolescent offspring was obese (mean BMI percentile $98.4 \pm 1.93$ ). The TDT revealed an overtransmission of the $\mathrm{C}$ allele to the obese offspring ( $\mathrm{p}=$ 0.0017), indicating that rs7566605 is associated with BMI from an early age on. A meta-analysis comprising all four case-control samples showed that the $\mathrm{CC}$ genotype was, under a recessive model, significantly associated with obesity $(\mathrm{OR}=1.22$; $95 \%-C I 1.05-1.42 ; \mathrm{p}=0.008$ [9]). Several attempts to replicate the INSIG2 finding have been or are currently being undertaken. Both confirmations [13] as well as negative findings [10-12] have been reported. Currently, data are being compiled for a large-scale meta-analysis which will in the near future help to clarify if INSIG2 is a real polygene.

\section{Fat Mass and Obesity Associated Gene}

One of the genes picked up in GWA studies for T2DM was FTO $[4,6]$. Frayling et al. [4] statistically adjusted for BMI and thus found that the association actually pertained to obesity, and not to T2DM. Confirmation for obesity in 13 cohorts with a total of 38,759 individuals and a meta-analysis finally showed that the A-allele of the variant rs9939609 is associated with a $31 \%$ increased risk to develop obesity. The $16 \%$ of adults who are homozygous for the risk allele on average weighed about 3 kilograms more and had a 1.67-fold increased odds for obesity when compared with those not inheriting a risk allele. Subsequently, an additional confirmation in a total of 25,508 European individuals was done $[5,7,53]$. Non-confirmation was reported in Asian populations [54,55].

The first GWA (Mapping 100K Set) for early onset extreme obesity was recently performed in 487 extremely obese German children and adolescents and 442 lean controls (case-control). Because only individuals of the opposite ends of the quantitative distribution BMI were included, this study was highly powered to detect obesity genes. It was the first GWA with a primary focus on obesity (obesity GWA). Additive, re- cessive and dominant models were analyzed with the main focus on the additive model based on the theory of additive effects of common alleles [56]. Six SNPs in FTO showed the strongest evidence for association with obesity (best SNP: rs1121980; additive model: nominal $\mathrm{p}=0.0000001129$; OR for heterozygosity and homozygosity for the risk T-allele 1.67 and 2.76, respectively [8]). Of the best 15 GWA hits 11 SNPs including two FTO SNPs were subsequently genotyped in 644 independent obesity families based on at least one young obese index patient. FBAT revealed confirmation of the initial finding just for the two FTO SNPs (both corrected $\mathrm{p} \leq 0.01$ ). Of the 9 other SNPs none of the risk alleles was associated with obesity in the independent families. Hence, this first obesity GWA represents a further proof of concept for GWAs to detect genes relevant for highly complex phenotypes such as obesity and demonstrates the power of carefully selected patient samples.

In a previous case-control study, which also comprised obese German children, the best SNP rs1421085 showed a nominal $\mathrm{p}=3.46 \times 10^{-7}$ (log-additive OR for the risk allele: $1.69,95 \%$ CI 1.38-2.06 [5]). The best SNP rs1121980 of the obesity GWA is located near that SNP and linkage disequilibrium is high so that it is not surprising that similar estimated genetic effect sizes were found. Effect sizes for the best markers derived from GWA data sets have been described to be usually overestimated [61]. In our obesity GWA [8] it was shown that this will not always be true.

\section{FTO in Asian Populations}

Association between three FTO variants (rs8050136, rs 9939609 and rs9930506) and obesity and related traits was analyzed in a population-based study of 3,210 unrelated Chinese Hans from Shanghai and Beijing. None of the FTO SNPs were found to be associated with obesity, overweight, BMI, waist circumference and body fat percentage, fasting levels of plasma glucose, HbA1c, insulin and beta-cell function (estimated as HOMA-B) under either additive or dominant models in quantitative trait analyses. Hence, a major role of FTO variants for obesity was not detected in a Chinese Han population [54]. Additionally, investigation of population frequencies of FTO variants in six Oceanic populations (Melanesians, Micronesians, and Polynesians) revealed no significant association between the FTO polymorphisms and BMI. The population frequencies ranged between 4.2 and $30.3 \%$ in the six Oceanic populations and were similar to those in Southeast and East Asian populations. Hence, there is no evidence to support that FTO polymorphisms underscore the thrifty genotype hypothesis for Oceanic populations [55].

\section{FTO and Age Effects}

The FTO SNPs were shown to be relevant for obesity in both children and adults [4, 5, 7]. In our obesity GWA [8] the effect of the FTO alleles was found to be relevant for both the younger and older children of the study group (determined by 
median split and analyses of both subgroups). Hence, it is not an effect that is valid only for adolescents. Frayling et al. [4] had originally reported that the association is detectable at 7 years of age already. It persists into the pre-pubertal period and beyond. A meta-analysis addressing developmental aspects should be able to detect a possible age-related effect of the $F T O$ variants.

\section{FTO and Physical Activity}

FTO rs9939609 was genotyped in a total of 17,508 middleaged Danes. Again, the A-allele was associated with overweight ( $\mathrm{p}=1 \times 10^{-12}$, OR 1.19,95\%-CI 1.13-1.24) and obesity ( $\mathrm{p}=2 \times 10^{-16}$, OR 1.27, 95\%-CI 1.20-1.34). Obesity-related quantitative traits such as body weight, waist circumference, fat mass, and fasting serum leptin levels were significantly elevated in A-allele carriers. There was an interaction between the FTO rs9939609 genotype and physical activity ( $\mathrm{p}=0.007)$, whereby physically inactive homozygous risk A-allele carriers had an increased BMI of $1.95 \pm 0.3 \mathrm{~kg} / \mathrm{m}^{2}$ compared with homozygotes for the T-allele. Hence, low physical activity seems to accentuate the effect of FTO rs9939609 on body fat accumulation [53].

\section{FTO in Linkage Scans}

Interestingly, the chromosomal region harboring FTO had been detected in genome-wide linkage scans. The FTO gene locus at chromosome 16q12.2 showed nominal evidence for linkage. However, the overall distribution of summed rank $\mathrm{p}$ values below 0.05 was not different from that expected by chance. Nonetheless it is noteworthy that FTO maps to one of the highest ranking bins determined in a meta-analysis of linkage studies for obesity [24].

\section{Functional Analyses of Fto in Animal Models}

Very recently, the function the FTO protein has been studied by detailed computational analysis of the sequence and predicted structure of the protein encoded by FTO. The analysis suggested that human FTO is a member of the non-heme dioxygenase (Fe(II)- and 2-oxoglutarate-dependent dioxygenases) superfamily $[57,58]$. The hypothesis was supported by amino acid conservation patterns. Both 2-oxoglutarate and iron should be important for FTO function [58]. Recombinant murine Fto catalyzed the Fe(II)- and 2OG-dependent demethylation of 3-methylthymine in single-stranded DNA. Concomitantly succinate, formaldehyde, and carbon dioxide are produced. Fto localizes to the nucleus in transfected cells which is consistent with a potential role in nucleic acid demethylation. In wild-type mice Fto mRNA is most abundant in the brain, especially in hypothalamic nuclei governing energy balance. In the arcuate nucleus Fto mRNA levels are regulated by feeding and fasting. Future studies will determine the physiologically relevant FTO substrate and how nucleic acid methylation status is linked to an elevated fat mass [57].

\section{Functional Analyses of FTO in Humans}

In humans the obesity risk variant rs8050136 was associated with a reduced insulin effect on beta activity, which implicates a lower cerebrocortical response to insulin. This might be a mechanism by which variation in FTO contributes to the pathogenesis of obesity [59]. Recently, Wåhlén et al. [60] suggested a role of the FTO gene in fat cell lipolysis, which may be important in explaining why the gene is implicated in body weight regulation.

\section{Conclusions and Perspectives}

Few solidly confirmed polygenes for body weight regulation have been described so far. The 103Ile allele (minor allele) of the $M C 4 R$ is to our knowledge the first confirmed variant conferring a protection from obesity. As most of the studies included in the respective meta-analyses pertained to adult obese cases, the polygenic effect is obviously not only relevant in children. The effect size of $-0.5 \mathrm{~kg} / \mathrm{m}^{2}$ of this allele on mean BMI has so far been assessed in adults only.

A novel genome wide scan employing a high-density SNP array led to the identification of a SNP in the vicinity of the INSIG2 which is seemingly relevant for body weight regulation in both children and adults. INSIG2 can currently be tentatively regarded as a polygene, as the frequency of homozygotes for the risk C-allele is high (about 10\%) and the conferred risk is relatively small $(\mathrm{OR}=1.33)$. However, there were a number of non-confirmations; a current meta-analysis will reveal if INSIG2 is a true polygene.

Very recently, the FTO gene was found to be associated with obesity as detected by GWA for T2DM. Large studies, including a meta-analysis, showed that risk alleles of specific FTO SNPs were associated with a substantially increased risk to develop obesity. The first GWA for extreme early onset obesity (case-control design) again substantiated the association of SNPs in FTO with obesity. This study was a proof of concept for GWA to detect genes relevant for highly complex phenotypes such as obesity and demonstrates the power of carefully selected patient samples.

The analysis of genetic factors involved in body weight regulation will substantiate the understanding of the underlying mechanism leading to obesity and hopefully eventually lead to optimized therapies.

\section{Acknowledgements}

This work was supported by grants from the Bundesministerium für Bildung und Forschung (NGFN2), the Deutsche Forschungsgemeinschaft (HE 1446/4-1) and the European Union (FP6 LSHMCT-2003-503041). 


\section{References}

1 Geller F, Reichwald K, Dempfle A, Illig T, Vollmert C, Herpertz S, Siffert W, Platzer M, Hess C, Gudermann T, Biebermann H, Wichmann HE, Schäfer H, Hinney A, Hebebrand J: Melanocortin-4 receptor gene variant I103 is negatively associated with obesity. Am J Hum Genet 2004;74:572-581.

2 Heid IM, Vollmert C, Hinney A, Döring A, Geller F, Löwel H, Wichmann HE, Illig T, Hebebrand J, Kronenberg F; KORA Group: Association of the 103I MC4R allele with decreased body mass in 7937 participants of two population based surveys. J Med Genet 2005;42:e21.

3 Young EH, Wareham NJ, Farooqi S, Hinney A, Hebebrand J, Scherag A, O'Rahilly S, Barroso I, Sandhu MS: The V103I polymorphism of the MC4R gene and obesity: population based studies and meta-analysis of 29563 individuals. Int J Obes (Lond) 2007;31:1437-1441.

4 Frayling TM, Timpson NJ, Weedon MN, Zeggini E, Freathy RM, Lindgren CM, Perry JR, Elliott KS Lango H, Rayner NW, Shields B, Harries LW, Barrett JC, Ellard S, Groves CJ, Knight B, Patch AM, Ness AR, Ebrahim S, Lawlor DA, Ring SM, BenShlomo Y, Jarvelin MR, Sovio U, Bennett AJ, Melzer D, Ferrucci L, Loos RJ, Barroso I, Wareham NJ, Karpe F, Owen KR, Cardon LR, Walker M, Hitman GA, Palmer CN, Doney AS, Morris AD, Smith GD, Hattersley AT, McCarthy MI: A common variant in the FTO gene is associated with body mass index and predisposes to childhood and adult obesity. Science 2007;316:889-894.

$\checkmark 5$ Dina C, Meyre D, Gallina S, Durand E, Korner A, Jacobson P, Carlsson LM, Kiess W, Vatin V, Lecoeur C, Delplanque J, Vaillant E, Pattou F, Ruiz J, Weill J, Levy-Marchal C, Horber F, Potoczna N, Hercberg S, Le Stunff C, Bougneres P, Kovacs P, Marre M, Balkau B, Cauchi S, Chevre JC, Froguel P: Variation in FTO contributes to childhood obesity and severe adult obesity. Nat Genet 2007;39:724-726.

6 Scott LJ, Mohlke KL, Bonnycastle LL, Willer CJ, Li Y, Duren WL, Erdos MR, Stringham HM, Chines PS, Jackson AU, Prokunina-Olsson L, Ding CJ, Swift AJ, Narisu N, Hu T, Pruim R, Xiao R, Li XY, Conneely KN, Riebow NL, Sprau AG, Tong M, White PP, Hetrick KN, Barnhart MW, Bark CW, Goldstein JL, Watkins L, Xiang F, Saramies J, Buchanan TA, Watanabe RM, Valle TT, Kinnunen L, Abecasis GR, Pugh EW, Doheny KF, Bergman RN, Tuomilehto J, Collins FS, Boehnke M: A genome-wide association study of type 2 diabetes in Finns detects multiple susceptibility variants. Science 2007;316:1341-1345.

7 Scuteri A, Sanna S, Chen WM, Uda M, Albai G, Strait J, Najjar S, Nagaraja R, Orru M, Usala G, Dei M, Lai S, Maschio A, Busonero F, Mulas A, Ehret GB, Fink AA, Weder AB, Cooper RS, Galan P, Chakravarti A, Schlessinger D, Cao A, Lakatta E, Abecasis GR: Genome-wide association scan shows genetic variants in the FTO gene are associated with obesity-related traits. PLoS Genet 2007; 3:e115.

8 Hinney A, Nguyen TT, Scherag A, Friedel S, Brönner G, Müller TD, Grallert H, Illig T, Wichmann HE, Rief W, Schäfer H, Hebebrand J: Genomewide scan for early onset extreme obesity supports the role of fat mass and obesity associated gene (FTO) variants. PLoS ONE 2007;2:e1361.
9 Herbert A, Gerry NP, McQueen MB, Heid IM, Pfeufer A, Illig T, Wichmann HE, Meitinger T, Hunter D, Hu FB, Colditz G, Hinney A, Hebebrand J, Koberwitz K, Zhu X, Cooper R, Ardlie K, Lyon $\mathrm{H}$, Hirschhorn JN, Laird NM, Lenburg ME, Lange $\mathrm{C}$, Christman MF: A common genetic variant is associated with adult and childhood obesity. Science 2006;312:279-283.

10 Dina C, Meyre D, Samson C, Tichet J, Marre M, Jouret B, Charles MA, Balkau B, Froguel P: Comment on 'A common genetic variant is associated with adult and childhood obesity'. Science 2007; 315:187.

11 Loos RJ, Barroso I, O'Rahilly S, Wareham NJ: Comment on 'A common genetic variant is associated with adult and childhood obesity'. Science 2007;315:187.

12 Rosskopf D, Bornhorst A, Rimmbach C, Schwahn C, Kayser A, Krüger A, Tessmann G, Geissler I, Kroemer HK, Völzke H: Comment on 'A common genetic variant is associated with adult and childhood obesity'. Science 2007;315:187.

13 Lyon HN, Emilsson V, Hinney A, Heid IM, LaskySu J, Zhu X, Thorleifsson G, Gunnarsdottir S, Walters GB, Thorsteinsdottir U, Kong A, Gulcher J, Nguyen TT, Scherag A, Pfeufer A, Meitinger T, Bronner G, Rief W, Soto-Quiros ME, Avila L, Klanderman B, Raby BA, Silverman EK, Weiss ST, Laird N, Ding X, Groop L, Tuomi T, Isomaa B, Bengtsson K, Butler JL, Cooper RS, Fox CS, O'Donnell CJ, Vollmert C, Celedon JC, Wichmann HE, Hebebrand J, Stefansson K, Lange C, Hirschhorn JN: The association of a SNP upstream of INSIG2 with body mass index is reproduced in several but not all cohorts. PLoS Genet 2007;3:e61.

14 Rankinen T, Zuberi A, Chagnon YC, Weisnagel SJ, Argyropoulos G, Walts B, Pérusse L, Bouchard C: The human obesity gene map: the 2005 update. Obesity (Silver Spring) 2006;14:529-644.

15 Pietiläinen KH, Kaprio J, Rissanen A, Winter T, Rimpelä A, Viken RJ, Rose RJ: Distribution and heritability of BMI in Finnish adolescents aged 16y and $17 \mathrm{y}$ : a study of 4884 twins and 2509 singletons. Int J Obes Relat Metab Disord 1999;23:107-115.

16 Fabsitz RR, Carmelli D, Hewitt JK: Evidence for independent genetic influences on obesity in middle age. Int J Obes Relat Metab Disord 1992;16: 657-666.

17 Saar K, Geller F, Rüschendorf F, Reis A, Friedel S, Schäuble N, Nürnberg P, Siegfried W, Goldschmidt HP, Schäfer H, Ziegler A, Remschmidt H, Hinney A, Hebebrand J: Genome scan for childhood and adolescent obesity in German families. Pediatrics 2003;111:321-327.

18 Chen W, Li S, Cook NR, Rosner BA, Srinivasan SR, Boerwinkle E, Berenson GS: An autosomal genome scan for loci influencing longitudinal burden of body mass index from childhood to young adulthood in white sibships: The Bogalusa Heart Study. Int J Obes Relat Metab Disord 2004;28: 462-469.

19 Meyre D, Lecoeur C, Delplanque J, Francke S, Vatin V, Durand E, Weill J, Dina C, Froguel P: A genome-wide scan for childhood obesity-associated traits in French families shows significant linkage on chromosome 6q22.31-q23.2. Diabetes 2004;53: 803-811.
Comuzzie AG, Hixson JE, Almasy L, Mitchell BD, Mahaney MC, Dyer TD, Stern MP, MacCluer JW, Blangero J: A major quantitative trait locus determining serum leptin levels and fat mass is located on human chromosome 2. Nat Genet 1997;15: 273-276.

21 Boutin P, Dina C, Vasseur F, Dubois S, Corset L, Séron K, Bekris L, Cabellon J, Neve B, Vasseur-Delannoy V, Chikri M, Charles MA, Clement K, Lernmark A, Froguel P: GAD2 on chromosome 10p12 is a candidate gene for human obesity. PLoS Biol 2003;1:e68.

22 Suviolahti E, Oksanen LJ, Ohman M, Cantor RM, Ridderstrale M, Tuomi T, Kaprio J, Rissanen A, Mustajoki P, Jousilahti P, Vartiainen E, Silander K, Kilpikari R, Salomaa V, Groop L, Kontula K, Peltonen L, Pajukanta P: The SLC6A14 gene shows evidence of association with obesity. J Clin Invest 2003;112:1762-1772.

23 Meyre D, Bouatia-Naji N, Tounian A, Samson C, Lecoeur C, Vatin V, Ghoussaini M, Wachter C, Hercberg S, Charpentier G, Patsch W, Pattou F, Charles MA, Tounian P, Clément K, Jouret B, Weill J, Maddux BA, Goldfine ID, Walley A, Boutin P, Dina C, Froguel P: Variants of ENPP1 are associated with childhood and adult obesity and increase the risk of glucose intolerance and type 2 diabetes. Nat Genet 2005;37:863-867.

24 Saunders CL, Chiodini BD, Sham P, Lewis CM, Abkevich V, Adeyemo AA, de Andrade M, Arya R, Berenson GS, Blangero J, Boehnke M, Borecki IB, Chagnon YC, Chen W, Comuzzie AG, Deng HW, Duggirala R, Feitosa MF, Froguel P, Hanson RL, Hebebrand J, Huezo-Dias P, Kissebah AH, Li W, Luke A, Martin LJ, Nash M, Ohman M, Palmer LJ, Peltonen L, Perola M, Price RA, Redline S, Srinivasan SR, Stern MP, Stone S, Stringham H, Turner S, Wijmenga C, A Collier D: Meta-analysis of genome-wide linkage studies in BMI and obesity. Obesity (Silver Spring) 2007;15:2263-2275.

25 Risch N, Merikangas K: The future of genetic studies of complex human diseases. Science 1996;273: 1516-1517.

26 Frayling TM: Genome-wide association studies provide new insights into type 2 diabetes aetiology. Nat Rev Genet 2007;8:657-662.

27 Neel JV: Diabetes mellitus: a 'thrifty' genotype rendered detrimental by 'progress'? Am J Hum Genet 1962;14:353-362.

28 Campbell H, Rudan I: Interpretation of genetic association studies in complex disease. Pharmacogenomics J 2002;2:349-360.

29 Spielman RS, McGinnis RE, Ewens WJ: Transmission test for linkage disequilibrium: the insulin gene region and insulin-dependent diabetes mellitus (IDDM). Am J Hum Genet 1993;52:506-516.

30 Huszar D, Lynch CA, Fairchild-Huntress V, Dunmore JH, Fang Q, Berkemeier LR, Gu W, Kesterson RA, Boston BA, Cone RD, Smith FJ, Campfield LA, Burn P, Lee F: Targeted disruption of the melanocortin-4 receptor results in obesity in mice. Cell 1997;88:131-141.

31 Vaisse C, Clement K, Guy-Grand B, Froguel P: A frameshift mutation in human MC4R is associated with a dominant form of obesity. Nat Genet 1998; 20:113-114.

32 Yeo GS, Lank EJ, Farooqi IS, Keogh J, Challis BG, O'Rahilly S: Mutations in the human melanocortin4 receptor gene associated with severe familial obesity disrupts receptor function through multiple molecular mechanisms. Hum Mol Genet 2003;12: 561-574. 
>33 Hinney A, Schmidt A, Nottebom K, Heibült O, Becker I, Ziegler A, Gerber G, Sina M, Görg T, Mayer H, Siegfried W, Fichter M, Remschmidt H, Hebebrand J: Several mutations in the melanocortin-4 receptor gene including a nonsense and a frameshift mutation associated with dominantly inherited obesity in humans. J Clin Endocrinol Metab 1999;84:1483-1486.

34 Hinney A, Hohmann S, Geller F, Vogel C, Hess C, Wermter AK, Brokamp B, Goldschmidt $\mathrm{H}$ Siegfried W, Remschmidt H, Schäfer H, Gudermann T, Hebebrand J: Melanocortin-4 receptor gene: case-control study and transmission disequilibrium test confirm that functionally relevant mutations are compatible with a major gene effect for extreme obesity. J Clin Endocrinol Metab 2003;88: $4258-4267$.

35 Hinney A, Bettecken T, Tarnow P, Brumm H, Reichwald K, Lichtner P, Scherag A, Nguyen TT, Schlumberger P, Rief W, Vollmert C, Illig T, Wichmann HE, Schäfer H, Platzer M, Biebermann H, Meitinger T, Hebebrand J: Prevalence, spectrum, and functional characterization of melanocortin-4 receptor gene mutations in a representative population-based sample and obese adults from Germany. J Clin Endocrinol Metab 2006;91:1761-1769.

36 Farooqi IS, O'Rahilly S: Monogenic obesity in humans. Annu Rev Med 2005:56:443-458.

37 Lubrano-Berthelier C, Dubern B, Lacorte JM, Picard F, Shapiro A, Zhang S, Bertrais S, Hercberg S, Basdevant A, Clement K, Vaisse C: Melanocortin 4 receptor mutations in a large cohort of severely obese adults: prevalence, functional classification, genotype-phenotype relationship, and lack of association with binge eating. J Clin Endocrinol Metab 2006;91:1811-1818.

38 Dempfle A, Hinney A, Heinzel-Gutenbrunner M, Raab M, Geller F, Gudermann T, Schäfer H, Hebebrand J: Large quantitative effect of melanocortin4 receptor gene mutations on body mass index. J Med Genet 2004;41:795-800.

39 Gotoda T, Scott J, Aitman TJ: Molecular screening of the human melanocortin-4 receptor gene: identification of a missense variant showing no association with obesity, plasma glucose, or insulin. Diabetologia 1997;40:976-979.

40 Xiang Z, Litherland SA, Sorensen NB, Proneth B, Wood MS, Shaw AM, Millard WJ, Haskell-Luevano C: Pharmacological characterization of 40 human melanocortin-4 receptor polymorphisms with the endogenous proopiomelanocortin-derived agonists and the agouti-related protein (AGRP) antagonist. Biochemistry 2006; 45:7277-7288

41 Biebermann H, Castaneda TR, van Landeghem F, von Deimling A, Escher F, Brabant G, Hebebrand J, Hinney A, Tschop MH, Gruters A, Krude H: A role for beta-melanocyte-stimulating hormone in human body-weight regulation. Cell Metab 2006;3: 141-146.
42 Stutzmann F, Vatin V, Cauchi S, Morandi A, Jouret B, Landt O, Tounian P, Levy-Marchal C, Buzzetti R, Pinelli L, Balkau B, Horber F, Bougnères P, Froguel $\mathrm{P}$, Meyre D: Non-synonymous polymorphisms in melanocortin-4 receptor protect against obesity: the two facets of a Janus obesity gene. Hum Mol Genet 2007;16:1837-1844.

43 Wellcome Trust Case Control Consortium: Genome-wide association study of 14,000 cases of seven common diseases and 3,000 shared controls. Nature 2007;447:661-678.

44 Christensen K, Murray JC: What genome-wide association studies can do for medicine. N Engl J Med 2007:356:1094-1097.

45 Sladek R, Rocheleau G, Rung J, Dina C, Shen L, Serre D, Boutin P, Vincent D, Belisle A, Hadjadj S, Balkau B, Heude B, Charpentier G, Hudson TJ, Montpetit A, Pshezhetsky AV, Prentki M, Posner BI, Balding DJ, Meyre D, Polychronakos C, Froguel P: A genome-wide association study identifies novel risk loci for type 2 diabetes. Nature 2007;445: 881-885.

46 Ioannidis JP, Patsopoulos NA, Evangelou E: Heterogeneity in meta-analyses of genome-wide association investigations. PLoS ONE 2007;2:e841.

47 Van Steen K, McQueen MB, Herbert A, Raby B, Lyon H, Demeo DL, Murphy A, Su J, Datta S, Rosenow C, Christman M, Silverman EK, Laird NM, Weiss ST, Lange C: Genomic screening and replication using the same data set in family-based association testing. Nat Genet 2005;37:683-691.

48 Lange C, DeMeo D, Silverman EK, Weiss ST, Laird NM: PBAT: tools for family-based association studies. Am J Hum Genet 2004;74:367-369.

49 Lange C, Lyon H, DeMeo D, Raby B, Silverman EK, Weiss ST: A new powerful non-parametric two-stage approach for testing multiple phenotypes in family-based association studies. Hum Hered 2003;56:10-17.

50 Laird NM, Horvath S, Xu X: Implementing a unified approach to family-based tests of association. Genet Epidemiol 2000;19(suppl 1):S36-42.

51 Horvath S, Xu X, Laird NM: The family based association test method: strategies for studying general genotype - phenotype associations. Eur J Hum Genet 2001:9:301-306.

52 Lange C, DeMeo DL, Laird NM: Power and design considerations for a general class of family-based association tests: quantitative traits. Am J Hum Genet 2002;71:1330-1341

53 Andreasen $\mathrm{CH}$, Stender-Petersen KL, Mogensen MS, Torekov SS, Wegner L, Andersen G, Nielsen AL, Albrechtsen A, Borch-Johnsen K, Rasmussen SS, Clausen JO, Sandbaek A, Lauritzen T, Hansen L, Jorgensen T, Pedersen O, Hansen T: Low physical activity accentuates the effect of the FTO rs9939609 polymorphism on body fat accumulation. Diabetes 2008;57:95-101.
54 Li H, Wu Y, Loos RJ, Hu FB, Liu Y, Wang J, Yu Z, Lin X: Variants in FTO gene are not associated with obesity in a Chinese Han population. Diabetes 2008;57:264-268.

55 Ohashi J, Naka I, Kimura R, Natsuhara K, Yamauchi T, Furusawa T, Nakazawa M, Ataka Y, Patarapotikul J, Nuchnoi P, Tokunaga K, Ishida T, Inaoka T, Matsumura Y, Ohtsuka R: FTO polymorphisms in oceanic populations. J Hum Genet 2007; 52:1031-1035.

56 Diabetes Genetics Initiative of Broad Institute of Harvard and MIT, Lund University, and Novartis Institutes of BioMedical Research, Saxena R, Voight BF, Lyssenko V, Burtt NP, de Bakker PI, Chen H, Roix JJ, Kathiresan S, Hirschhorn JN, Daly MJ, Hughes TE, Groop L, Altshuler D, Almgren P, Florez JC, Meyer J, Ardlie K, Bengtsson Boström $\mathrm{K}$, Isomaa B, Lettre $\mathrm{G}$, Lindblad U, Lyon HN, Melander $\mathrm{O}$, Newton-Cheh $\mathrm{C}$, Nilsson $\mathrm{P}$, Orho-Melander M, Råstam L, Speliotes EK, Taskinen MR, Tuomi T, Guiducci C, Berglund A, Carlson J, Gianniny L, Hackett R, Hall L, Holmkvist J, Laurila E, Sjögren M, Sterner M, Surti A, Svensson M, Svensson M, Tewhey R, Blumenstiel B, Parkin M, Defelice M, Barry R, Brodeur W, Camarata J, Chia N, Fava M, Gibbons J, Handsaker B, Healy C, Nguyen K, Gates C, Sougnez C, Gage D, Nizzari M, Gabriel SB, Chirn GW, Ma Q, Parikh H, Richardson D, Ricke D, Purcell S: Genome-wide association analysis identifies loci for type 2 diabetes and triglyceride levels. Science 2007;316:1331-1336.

57 Gerken T, Girard CA, Tung YC, Webby CJ, Saudek V, Hewitson KS, Yeo GS, McDonough MA, Cunliffe S, McNeill LA, Galvanovskis J, Rorsman P, Robins P, Prieur X, Coll AP, Ma M, Jovanovic Z, Farooqi IS, Sedgwick B, Barroso I, Lindahl T, Ponting CP, Ashcroft FM, O'Rahilly S, Schofield CJ: The obesity-associated FTO gene encodes a 2oxoglutarate-dependent nucleic acid demethylase. Science 2007;318:1469-1472.

58 Sanchez-Pulido L, Andrade-Navarro MA: The FTO (fat mass and obesity associated) gene codes for a novel member of the non-heme dioxygenase superfamily. BMC Biochem 2007;8:23.

59 Tschritter O, Preissl H, Yokoyama Y, Machicao F, Haring HU, Fritsche A: Variation in the FTO gene locus is associated with cerebrocortical insulin resistance in humans. Diabetologia 2007;50: 2602-2603.

60 Wåhlén K, Sjölin E, Hoffstedt J: The common rs 9939609 gene variant of the fat mass and obesity associated gene (FTO) is related to fat cell lipolysis. J Lipid Re 2007; Nov 29; [Epub ahead of print].

61 Edwards BJ, Haynes C, Levenstien MA, Finch SJ, Gordon D: Power and sample size calculations in the presence of phenotype errors for case/control genetic association studies. BMC Genet 2005;6:18. 